\title{
Analysis of Tomato Value Chain: The Case of Toke Kutaye District, West Shawa Zone, Oromia National, Regional Stat
}

\author{
Aman Rikitu \\ Department of Agricultural Economics, College of Agriculture and Veterinary Science \\ Ambo University, Ethiopia \\ aman.rikitu@gmail.com
}

\begin{abstract}
The main purpose of this paper was to examine tomato value chain and the problem faced by different chain actors. Vegetable production plays important role in poverty improvement through employment generation, improving the feeding behavior of the people, and creating new opportunities for poor farmers. Value chain analysis is a tool that facilitates the investigation of the business operations of industry in terms of new value adding opportunities as well as accessible value adding activities with regards to foundation of factor inputs, primary processing and delivery of the finished product. Structured questionnaires were managed to 150 farmers respondents, 30 tomato traders and 5 input suppliers' members. The data were collected in 2015 from 5 kebeles, a major tomato growing area in the Toke Kutaye district West Shawa Zone of oromia. OLS regeration model was used to analyze the extent of constraints of the tomato value chain by respondents. The major problems confronting tomato value chain were found to be distance from market, own land, tomato yield, and price expectation, While farmers ranked price expectation as their most worrying constraint, of tomato value chain participation decision of Toke Kutaye's farm householders. The paper recommends that interventions in the value chain should be coordinated in a manner as to affect all actors, taking into consideration their specific priority needs.
\end{abstract}

Keyterms: Value Chain, Tomato, OLS Wholesalers, Retailers, Farmers Toke Kutaye

\section{INTRODUCTION}

\section{Background of the Study}

Ethiopia has a variety of vegetable crops grown in different agro ecological zones produced through commercial as well as small farmers both as a source of income as well as food. However, the type is limited to few crops and production is concentrated to some pocket areas. In spite of this, the production of vegetables varies from cultivating a few plants in the backyards for home consumption up to a large-scale production for domestic and export markets (Zylberberg, 2014; Weignberger and Lumpkin, 2005).

Value chain analysis is a tool that facilitates the investigation of the business operations of industry in terms of new value adding opportunities as well as existing value adding activities with regards to sourcing of factor inputs, primary processing and delivery of the finished product. In its execution, VC entails mapping the value adding activities of a product in terms of logistics and in-plant operations as it passes from one stage of processing to the next in the chain. This form of analysis is conducted at the firm level, where the findings and observations are drawn for the firm and inferred for the industry as a whole. In agricultural value chains, primary actors perform a selection of (primary) functions, which typically include input supply, production, processing, storage, wholesale (including export), retail and consumption(Ricketts et al., 2014). Actors who perform similar functions are regarded as occupying the same functional 'node', referred to as, for example, the input supply node, production node, retail node, and so on. 
Analysis of Tomato Value Chain: The Case of Toke Kutaye District, West Shawa Zone, Oromia National, Regional Stat

Taking a value chain approach to economic development and poverty reduction (that includes creation of Decent Jobs) involves addressing major constraints and capitalizing on opportunities faced by input suppliers, producers, processors, traders and other businesses at multiple levels and points along a given value chain. This will inevitably include a wide range of activities such as improving access to necessary inputs, developing the capacity and skills of human resources, improving working conditions and productivity, strengthening the delivery of business and financial services, enabling the flow of information, facilitating improved market access, or increasing access to higher-value markets or value-added products(Hamprecht et al.,2005). Value chain analysis identifies opportunities and constraints of a particular local/regional sector and analysis its market integration. The end result is an action plan or implementation matrix that proposes various solutions addressing identified opportunities and constraints (ILO, 2014).

In the areas where irrigation water is available and farmers have better agricultural marketing networks, horticulture production is a major source of cash income for the households and one of the major sources of livelihood for a large number of transporters, middlemen and traders in the area (Bezabih and Hadera, 2007 as cited in Abrham, 2013).The lack of a shift from subsistence to commercial farming in spite of such comparative advantage may have different reasons like high risks, high transaction costs, limited food markets, limited insurance options and limited access to credit or in general the problem in the value chain.

Problems in the tomato value chain hinder the potential gains that could have been attained from the existing opportunities. In this regard, tomato value chain analysis is an interesting process that has not been investigated much in the study areas. Both buyers and sellers in the study areas usually do not play collective roles towards one another and there are no tomato processing activities. Under such circumstances, a study that focused on production problems, marketing problems, and roles and responsibilities of actors can play significant role towards the improvements of the existing system.

The main challenge facing tomato producers in T/Kutaye is improved seeds, market opportunity, market fluctuation, post-harvest, producers unable to set the price and production seasonality (TKIA0, 2014). Seasonality is more evident in perishable crops such as fruits and vegetables which allow for a small time lag between harvest and usage (Amikuzuno, and Ihle, 2010). As supply decreases prices are adjusted upwards and vice versa. The producer cannot move up the value chain due to a lack of supporting services that augment weak horizontal and vertical linkages. The nature of production and entrenched cultural practices does not facilitate the organization or collaboration of individual farmers into a group dynamic. Individuals have different financial requirements that inhibit the formation of groups or associations. When examining the support services to the tomato value chain it is the lack of information that is the main constraining factor. Due to the many trading levels, and the fragmentation of tomato value chain actors, information is disjointed and lost down the chain. In particular the lack of market knowledge at the producer level prevents efforts to increase the competiveness of the chain. In this regard, vegetable value chain analysis is an interesting process that has not been investigated much in the study areas. Farther more, no research was conducted on tomato value chain analysis in the study area before and also its economic benefit has not been measured. Therefore, it is necessary to find out tomato value chain analysis at Toke kutaye district,WestShawa, Oromia National Regional state with the following objectives.

$>\quad$ To identify tomato value chain and examine the performance of the chain actors

$>\quad$ To identify major constraints and opportunities in tomato value chain

American Research Journal of Agriculture

Page 2 
Analysis of Tomato Value Chain: The Case of Toke Kutaye District, West Shawa Zone, Oromia National, Regional Stat

\section{MATERIALS AND METHOdS}

\section{Description of Study Area}

The research was conducted at Toke Kutaye district, West Shewa zone, Oromia region which is located $132 \mathrm{~km}$ to the west of Addis Ababa. The area lies between $09^{\circ} 04^{\prime} \mathrm{N}$ latitude and 38 $38^{\prime}$ E longitude at an elevation of $2390 \mathrm{~m}$.asl. Its mean annual rainfall is $1100 \mathrm{~mm}$ with mean maximum and minimum air temperature $22.2^{\circ} \mathrm{C}$ and $6.13^{\circ} \mathrm{C}$, respectively. The soil type is Vertisols and Nitosols (EARI, 2008).according to the documents from West ShewaZone testimony, Toke Kutaye is one of the potential tomato growing area of the zone and has good potential for future. Most farmer in the district produce tomato for their livelihoods. In the district there is a total area of 44,012ha farm land out of which 37,192ha are productive. During 2013 and 2014 the total area covered by tomato are 1,151 ha (TKADO,2015).

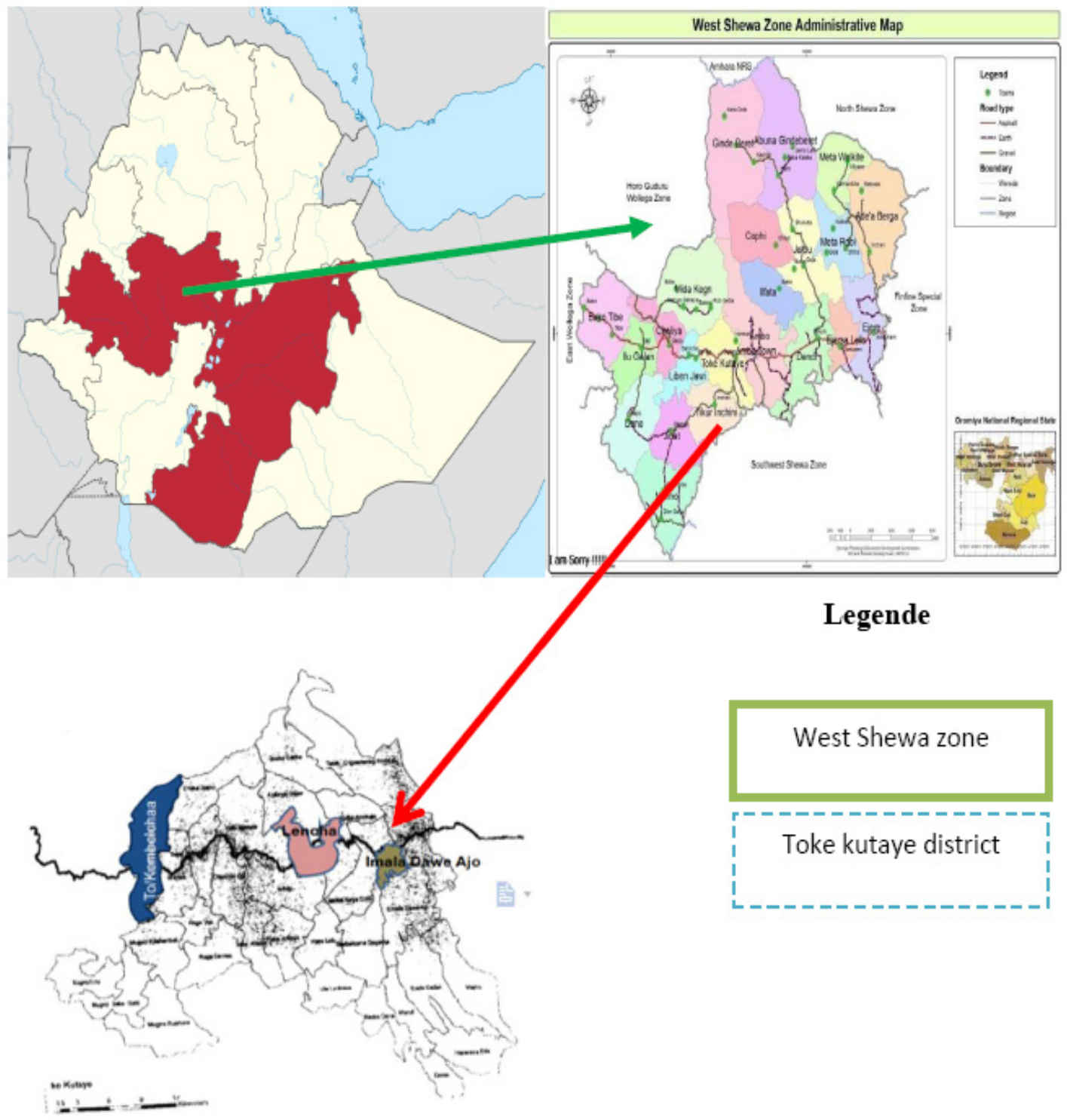

Figure1. Geographical location of study area 
Analysis of Tomato Value Chain: The Case of Toke Kutaye District, West Shawa Zone, Oromia National, Regional Stat

\section{Sampling Techniques and Data Collection}

The survey work was undertaken in Toke Kutaye where tomato is potentially produced. Primary data were collect from 150 randomly selected smallholder producers which will proportionally distributed among the five different study kebeles. Focus Group Discussions (FGDs) and Key Informant Interviews (KIIs) were held with staff of the district Irrigation authority office during 2015 and also 30 tomato traders and 5 input suppliers' members. Qualitative and quantitative data were gathered by employing a structured questionnaire. Before launching the survey, questionnaire will pretest and was improved accordingly. FGDs and KIIs were guided by checklists prepared for the study purpose. The data on area, production and yield will obtained from District Agriculture office 20012-2014. Primary data will be collected through structured questionnaire from main factors such as farmers, input supplier (research institution and NGOs), support providers (Bureaus of Agriculture) and traders. For each actor a separate questionnaire were prepared and administered for assessment. The field survey was carried out in tomato growing areas of the district.

Table 1. sample size distribution in the sample rural kebeles

\begin{tabular}{|l|l|l|l|}
\hline $\begin{array}{l}\text { Name of the } \\
\text { District }\end{array}$ & Name of the Kebeles & $\begin{array}{l}\text { Total number of } \\
\text { Tomato producers }\end{array}$ & $\begin{array}{l}\text { Number of sample } \\
\text { households }\end{array}$ \\
\hline \multirow{3}{*}{ Toke Kutaye } & DaweAjo & 150 & 27 \\
\cline { 2 - 4 } & Nega file & 170 & 30 \\
\cline { 2 - 4 } & Birbirsa and Dogoma & 200 & 36 \\
\cline { 2 - 4 } & Maruf & 180 & 32 \\
\cline { 2 - 4 } & Lencha & 140 & 25 \\
\hline
\end{tabular}

\section{Data Analysis}

To analyze the collected data both descriptive statistics and econometrics analysis (OLS) and value chain map were used.

\section{Descriptive and inferential statistics}

These methods of data analysis refer to the use of percentages, standard deviations, $t$-test, $\chi 2$-test, and maps in the process of examining and describing value chain functions, facilities, services, and household characteristics.

\section{Econometrics analysis}

Econometric analysis was used for the analysis of determinants of tomato marketed surplus at farm level. All sample tomato producers supply tomato to the market. The dependent variable is quantity of tomato supplied to market which is a continuous variable. Hence, to identify the determinants of quantity of tomato supplied to market by small holder farmers, multiple linear regression model (OLS) was employed. Following Green (2003), the multiple linear regression model was specified as;

$Y=\beta_{0}+\beta i \mathrm{X} i+U$

Where:

$Y=$ quantity of tomato supplied to market in the production season (quintal/year)

$\mathrm{Xi}=\mathrm{a}$ vector of explanatory variables $\beta \mathrm{i}=\mathrm{a}$ vector of parameters to be estimated

$U=$ disturbance term 
Analysis of Tomato Value Chain: The Case of Toke Kutaye District, West Shawa Zone, Oromia National, Regional Stat

\section{Value chain analysis}

As products move successively through the various stages, transactions take place between multiple chain actors, money and information are exchanged and value was progressively added. The analysis of tomato value chains highlights the need for enterprise development, enhancement of product quality, and quantitative measurement of value addition along the chain, promotion of coordinated linkages among producers and improvement of the competitive position of individual enterprises in the marketplace. Moreover, individual enterprises may feed into numerous chains; hence, which chain (or chains) was/were targeted depends largely on the point of entry for the research inquiries (Kaplinsky and Morris, 2001). The following value chain analysis was applied to this study:

$>$ Mapping the value chain to understand the characteristics of the chain actors and the relationships among them, including the study of all actors in the chain, of the flow of tomato through the chain, of employment features, and of the destination and volumes of domestic sales. This information can be obtained by conducting surveys and interviews as well as by collecting secondary data from various sources.

$>$ Identifying the distribution of actors' benefits in the chain. This involves analyzing the margins and profits within the chain and therefore determined who benefits from participating in the chain and who would need support to improve performance and gains. In the prevailed context of market liberalization, this step is particularly important, since the poor involved in value chain promotion were the most vulnerable.

\section{Analysis of tomato value chain performance}

Estimates of the value margins are the best tools to analyze performance of a value chain at each level of the chain. Value margin will be calculated by taking the difference between producers and retail economic prices. The producers' share is the commonly employed ratio calculated mathematically as, the ratio of producers' economic price to consumers' price. Mathematically, producers' share can be expressed as:

$\mathrm{PS}=\frac{P_{E p}}{C_{p}}=1-\frac{V M}{C_{P}}$

where: PS= Producer's share

PEp= Producer's economic price

$\mathrm{Cp}=$ Consumer price

$\mathrm{VM}=$ value margin

The above equation tells us that a higher value margin, diminishes producers share and vice versa. It also provides an indication of welfare distribution among production and value chain agents.

Calculating the total value margin was done by using the following formula. Computing the Total Gross value Margin (TGVM) is always related to the final price paid by the end buyer and is expressed as a percentage (Mendoza, 1995)

$\mathrm{TGVM}=\frac{\text { consumerprice-producerprice }}{\text { consumerprice }} X 100$.

where, TGVM=Total gross value margin. 
Analysis of Tomato Value Chain: The Case of Toke Kutaye District, West Shawa Zone, Oromia National, Regional Stat

Net Value Margin (NVM) is the percentage over the final price earned by the intermediary as his net income once his value chain costs are deducted. The equation tells us that a higher value margin diminishes the producer's share and vice-versa. It also provides an indication of welfare distribution among production and value chain agents.

$\mathrm{NVM}=\frac{\text { grossvaluemergin -valuechaincost }}{\text { consumerprice }} X 100$.

From this measure, it is possible to see the allocative efficiency of value chain. Higher NVM or profit of the value chain intermediaries reflects reduced downward and unfair income distribution, which depresses value chain participation of smallholders. An efficient value chain system is where the net margin is near to reasonable profit.

Value margin at a given stage ' $\mathrm{j}$ ' (GVMj) was computed as:

$\mathrm{GVMj}=\frac{E P j-P P j}{T G V M} X 100$

Where, EPj is Economic price at $\mathrm{jth}$ link and PPj is purchase price at jth link.

Total gross profit margin also computed as:

TGPM=TGVM-TOE

Where, TGPM is total gross profit margin, TGVM is total gross value margin and TOE is total operating expense.

Similar concept of profit margin that deducts operating expense from value margin was done by Dawit (2010) and Marshal (2011).

Then profit margin at stage " $\mathrm{i}$ " is given as:

$\mathrm{GPMj}=\frac{G V M j-O E j}{T G P M} X 100$.

where, $\mathrm{GPMj}=$ Gross profit margin at jth link

$\mathrm{GVMj}=$ Gross value margin at jth link

$\mathrm{OEj}=$ Operating expense at jth link

TGPM=Total gross profit margin

\section{RESUltS AND Discussion}

\section{Descriptive Results}

\section{Demographic characteristics of sample households}

Tables 2 and 3 present demographic and socioeconomic characteristics of the sample respondents. The total sample size of farm respondents handled during the survey was 150. Of the total sample respondents, $99.3 \%$ were male-headed households and only $0.7 \%$ were female-headed in the district and Average household heads age was 40.7 . With regards to educational status of the householder showed $11.3 \%, 56.7 \%$ and $32 \%$ were illiterate, primary and above primary school respectively. This shows that practical based education is very important for that area. Farming was the main occupation and source of livelihood for all sample farmers $(100 \%)$ in the district. 
Analysis of Tomato Value Chain: The Case of Toke Kutaye District, West Shawa Zone, Oromia National, Regional Stat

Table 2. demographic and socioeconomic characteristics of samples households

\begin{tabular}{|c|c|c|c|}
\hline Variable & Items & Number & percent \\
\hline \multirow{3}{*}{ Sex } & Male & 149 & 99.3 \\
\cline { 2 - 4 } & Female & 1 & 0.7 \\
\hline \multirow{3}{*}{ Education } & illiterate & 17 & 11.3 \\
\cline { 2 - 4 } & Primary & 85 & 56.7 \\
\cline { 2 - 4 } & Above primary & 48 & 32 \\
\hline \multirow{3}{*}{ Marital status } & Single & 4 & 2.7 \\
\cline { 2 - 4 } & Married & 146 & 97.3 \\
\cline { 2 - 4 } & Divorced & 0 & 0 \\
\cline { 2 - 4 } & Widow & 0 & 0 \\
\hline
\end{tabular}

Source: Own computation from survey result, 2015

Table 3. Demographic and socioeconomic characteristics of samples

\begin{tabular}{|l|r|r|c|c|}
\hline \multicolumn{1}{|c|}{ variable } & Number & \multicolumn{1}{c|}{ mean } & \multicolumn{1}{c|}{ SD } & t-test \\
\hline Sex of household & 150 & .9933 & .08165 & 149.000 \\
\hline Age of household & 150 & 30.7067 & 9.55278 & 52.189 \\
\hline Education level & 150 & 2.2200 & .65405 & 41.571 \\
\hline Experience & 150 & 7.0608 & 6.14366 & 13.982 \\
\hline
\end{tabular}

Note: SD is standard deviation.

Source: Own computation from survey result, 2015

\section{Land Holding and Tomato Production Overview}

Landholding of the sample respondents ranges from 0.25 ha to 6ha with an average of 2.51 ha per household in Toke Kutaye district. In terms of allocation, in average $0.38 \mathrm{ha}(6 \%)$ were allocated to tomato production in the district. T-test result showed that there was a significant difference in land allocation to agricultural production.

Table 4. Type of major vegetables crops produced by sample households

\begin{tabular}{|c|c|c|c|}
\hline Variables & Mean & SD & t- value \\
\hline Total cultivated land & 1.8419 & 1.12 & 19.86 \\
\hline land for tomato & 0.3878 & 0.322 & 14.56 \\
\hline Land for onion & 11.727 & 11.62 & 11.97 \\
\hline
\end{tabular}

Note: SD stands for standard deviation

Source: Own computation from survey result, 2015

Some households produce combinations of vegetable types and others produce one type of vegetable. Almost 
Analysis of Tomato Value Chain: The Case of Toke Kutaye District, West Shawa Zone, Oromia National, Regional Stat

all of sample households produce tomato. Tomato production in toke kutaye district is undertaken only once a year which is more dependent of irrigation during winter season. There was a significant difference in vegetable production in this District. This is may be due to difference in production technology and natural resources between the households. Tomato and onion are the dominant vegetables produced by sample households in the study areas.

\section{Means of Livelihood}

The respondents depend on different means of income generation strategies where grain production was major sources of income for the majority of the producers in the district. For this reason, about $100 \%$ of the respondents earned their living from grain production as a primary source in the study area. Tomato production is also considered as the second major means of livelihood in this district (Toke kutaye district 2015 annual report). Similarly, tomato was the principal vegetable crops that support the livelihood of farming households in Toke kutaye.

\section{Producers Characteristics by the Level of Market Supply}

Tomato is produced mainly for market and the main cash crop for Toke Kutaye district. Very recently, the tomato markets have become so attractive that many actors' national prices served as the main driving force for tomato production. The study clearly indicated that on the average $87.3 \%$ of tomato production has been supplied to the market with significant difference among farmers in the given kebeles. The highest average proportion of production supplied to the market was observed in DaweAjo and Nega File (93\% and $96.45 \%$ respectively) and the lowest in Maruf (83\%) (table 7).

Table 5. Average proportion of tomato production sold by farmers, 2014/15

\begin{tabular}{|c|c|c|}
\hline kebele & $\begin{array}{c}\text { Average tomato production } \\
\text { (qt /household) }\end{array}$ & $\begin{array}{c}\text { Average proportion of } \\
\text { production sold }\end{array}$ \\
\hline DaweAjo & $58.15(58)$ & $93.32(46.96)$ \\
\hline Nega file & $37.78(44.09)$ & $96.45(44.08)$ \\
\hline Birbirsa and Dogoma & $20.86(18.41)$ & $85.45(17.75)$ \\
\hline Maruf & $22.13(15.39)$ & $83.34(14.80)$ \\
\hline Lencha & $39.32(20.46)$ & $88.25(23.61)$ \\
\hline F-value & $4.7^{* *}$ & $4.9^{* *}$ \\
\hline
\end{tabular}

Source: Survey result, 2015. Figures in parenthesis are standard deviations

Note: ** Significant at $5 \%$,

\section{Producers' Marketing Outlets}

In this study, tomato market outlets were identified as alternatives to farmers to sell majority of their tomato products. These were wholesalers which accounts for $(26.7 \%)$ of total sells followed by, retailers (43.3\%), processors $(16.7 \%)$ and the remaining brokers (13.3\%).Although the role of agricultural cooperatives in smallholder farmers marketing is recognized as vital, no single household reported cooperatives as alternative market outlet in their tomato marketing. As the following table 8 showed most of the farmers soled their product to retailers in which their market was very limited. This should be seen as serious policy concern for the government and other relevant stakeholders in this sector.Table 6. present demographic characteristics of sample respondents across marketing outlets 
Analysis of Tomato Value Chain: The Case of Toke Kutaye District, West Shawa Zone, Oromia National, Regional Stat

Table 6. Producers by demographic characteristics across marketing outlets

\begin{tabular}{|c|c|c|c|c|c|c|}
\hline \multirow[t]{2}{*}{ Variable } & \multirow[t]{2}{*}{ Items } & $\begin{array}{c}\text { Processors } \\
\mathrm{N}=5\end{array}$ & $\begin{array}{c}\text { wholesalers } \\
\qquad \mathrm{N}=8\end{array}$ & $\begin{array}{c}\text { Brokers } \\
\mathrm{N}=4\end{array}$ & \multicolumn{2}{|c|}{$\begin{array}{c}\text { retailers } \\
\mathrm{N}=13\end{array}$} \\
\hline & & $\mathrm{N} \quad \%$ & $\mathrm{~N} \quad \%$ & $\mathrm{~N} \quad \%$ & $\mathrm{~N}$ & $\%$ \\
\hline \multirow[t]{2}{*}{ sex } & Male & $5 \quad 100$ & $8 \quad 100$ & $4 \quad 100$ & 4 & 30.7 \\
\hline & Female & 0 & 0 & 0 & 96 & 9.3 \\
\hline \multirow[t]{4}{*}{ EDUC } & Illiterate & 00 & 00 & 0 & 5 & 7.5 \\
\hline & Primary school & $5 \quad 100$ & 337.5 & 250 & 53 & 8.46 \\
\hline & Secondary school & 0 & 562.5 & 250 & 8 & 61.54 \\
\hline & Diploma and above & 0 & 00 & 0 & 0 & 0 \\
\hline
\end{tabular}

source: survey result of 2015

\section{Role of Actors in Tomato Value Chain}

The primary actors in tomato value chain in Toke kutaye District were seed and other input suppliers, farmers, traders and consumers. Each of these actors adds value in the process of changing product title. Some functions or roles are performed by more than one actor, and some actors perform more than one role.

Input supply: Inputs such as seeds, fertilizer, and pesticides are supplied by farmers' cooperatives/unions. District level agriculture offices and irrigation authority in Toke Kutaye districts engage in input supply activities. Seeds of improved varieties are supplied by private traders. In sampled kebeles $91.3 \%$ of the sample respondents applied fertilizer to tomato field. In these kebeles the rate of fertilizer application was low. The reason indicated for not using fertilizer to tomato field and low rate of fertilizer application was high fertilizer price.

Table 7. Chemical fertilizer use by sample respondents

\begin{tabular}{|c|c|c|c|}
\hline fertilizers & Input used & \multicolumn{2}{|c|}{ Tomato N=150 } \\
\hline \multirow{2}{*}{ Urea } & & No & 91.30 \\
\hline \multirow{2}{*}{ Dap } & yes & 137 & 8.70 \\
\cline { 2 - 4 } & no & 13 & 94.60 \\
\cline { 2 - 4 } & yes & 142 & 5.3 \\
\hline \multirow{2}{*}{ Organic } & no & 8 & 94.00 \\
\cline { 2 - 4 } & yes & 141 & 6.00 \\
\hline \multirow{2}{*}{ Insecticide } & no & 9 & 10.7 \\
\cline { 2 - 4 } & nos & 16 & 89.3 \\
\hline Herbicide & yes & - & \\
\cline { 2 - 4 } & no & - & \\
\hline
\end{tabular}

source: survey result of 2015 
Analysis of Tomato Value Chain: The Case of Toke Kutaye District, West Shawa Zone, Oromia National, Regional Stat

\section{Tomato Value Chain Performance Analysis}

\section{Value chain analysis}

The analysis of value chain is intended to provide a systematic knowledge of the flow of the goods and services from their origin (producer) to the final destination (consumer). Value chain is a concept which can be simply described as the entire range of activities required to bring a product from the initial input-supply stage, through various phases of production, to its final market destination. The production stages entail a combination of physical transformation and the participation of various producers and services, and the chain includes the product's disposal after use. As opposed to the traditional exclusive focus on production, the concept stresses the importance of value addition at each stage, thereby treating production as just one of several value-adding components of the chain.

\section{Tomato value chain}

Six main alternative chains were identified for tomato marketing. It was estimated 16,575qtls that of tomato were marketed in Guder, Ambo, and Addis Abeba markets in 2014/15. From the total quantity marketed $4,538.25 \mathrm{qtls}$ of tomato are supplied by sample respondents. The main marketing channels identified from the point of production until the product reaches the final consumer through different intermediaries were depicted in Figure 2.

As can be understood from Figure 2 the main receivers from producers were retailers, wholesalers, processors and brokers $43.3 \%, 26.7 \%, 16.7 \%$, and $13.3 \%$ respectively. On top of this, channel comparison was made based on volume that passed through each channel. Accordingly, the chain of producer - wholesaler - retailer consumer carry on the largest followed by producer - retailers - consumer and producer- consumer; and that carry a volume of 2,615.5Qt, 1,350Qt and 572.75Qt in that order.
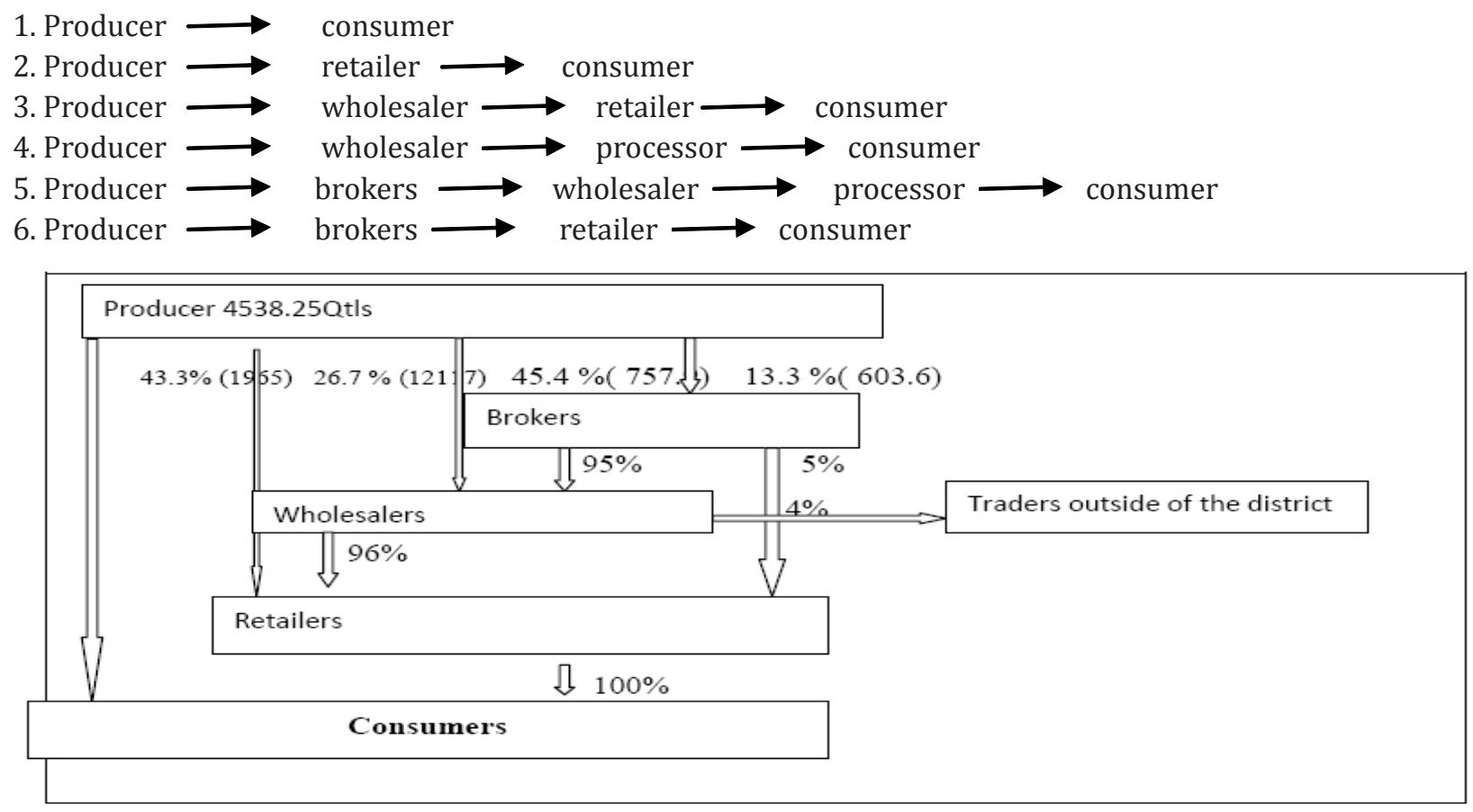

Figure 2. tomato market channels

Source: own survey data result 2015 
Analysis of Tomato Value Chain: The Case of Toke Kutaye District, West Shawa Zone, Oromia National, Regional Stat

\section{Performance of Tomato Value Chain}

The performance of tomato value chain was evaluated by considering associated costs, returns and value margins. The methods employed for analysis of performance were chain comparison and value margin. The analysis of value chain was intended to provide a systematic knowledge of the flow of goods and services from its origin of production to final destination (ultimate consumers). The estimated volume of production of tomato is $4,538.25 \mathrm{Q}$ tls.

The distribution of costs and gross income at different levels is important in the business of tomato. Being fresh tomato require greater attention during harvesting, packaging and transporting from the point of production to the final market. The marketing cost of the tomato mainly involves the cost of post-harvest activities incurred before reaching the consumer. This includes cost of harvesting and packaging (material and labor costs), handling (sorting, cleaning, grading, loading, and unloading), and transportation and tax costs. Generally, these components constitute a large share in the total margin between the final retailer value and the cost of production. The margin calculation is done to show the distribution throughout the various actors as tomato move from production to collectors, wholesalers, retail markets, and finally to consumers.

Value margin can be used to measure the share of the final selling price that is captured by a particular agent in the value chain. The relative size of various chain participants' gross margins can indicate where in the chain value is added and/or profits are made. In order to calculate the value margin of an agent, the value added of tomato for that particular agent was taken. For instance, the buying price of consumers was obtained by taking the average purchasing price of consumers. In order to measure the value added share of each agent, the value chain where all agents participated was selected. Value margins, associated costs and benefit share of value chain actors and value margins through different main channels was presented below.

Table 8. Tomato chain costs and value addition of actors

\begin{tabular}{|l|l|l|l|}
\hline \multicolumn{1}{|c|}{ Items (Birr/Qt) } & \multicolumn{1}{c|}{ Producers } & \multicolumn{1}{c|}{ Wholesalers } & \multicolumn{1}{c|}{ Retailers } \\
\hline Purchase price & - & 350 & 550 \\
\hline Production cost & 273.7 & - & - \\
\hline Chain cost & & & \\
\hline Labor & 10 & 15 & 15 \\
\hline transport & - & 20 & 20 \\
\hline loss & 20 & 32 & 40 \\
\hline Packing materials & 20 & 20 & 20 \\
\hline tax & - & 25 & 25 \\
\hline Total chain cost & $\mathbf{5 0}$ & $\mathbf{1 1 2}$ & $\mathbf{1 2 0}$ \\
\hline Total cost & 323.7 & 462 & 770 \\
\hline Value added & 350 & 550 & 820 \\
\hline Value margin & $\mathbf{7 6 . 3}$ & $\mathbf{2 0 0}$ & $\mathbf{2 7 0}$ \\
\hline Selling price/quintal & 370.0 & 700 & 900 \\
\hline Profit & 20.0 & 150 & 80.0 \\
\hline \%share of profit & 5.7 & 27.3 & 9.7 \\
\hline
\end{tabular}

Source: Own computation from survey result, 2015 
Analysis of Tomato Value Chain: The Case of Toke Kutaye District, West Shawa Zone, Oromia National, Regional Stat

Each of the tomato value chain actors adds value to the product as the product passes from one actor to another. In a way, the actors change the form of the product through improving the grade by sorting, cleaning or washing or create space and time utility. While farmers, doing all the work of producing tomato and bearing the associated risks, took only $5.7 \%$ but wholesalers gained $27.3 \%$ of the profit margin. This disproportionate share of benefits is the reflection of power relationship among actors.

\section{Production Constraints}

After setting the level of farm household level market surplus, it is important to identify the major factors that determine the level. Accordingly, about 11 variables were hypothesized to determine the household level of marketed supply.

Among the hypothesized 11 variables, only five were found to significantly affect the household level of quantity supplied to market (Table 11). Of the hypothesized variables; tomato yield, own land, distance from nearest market, getting training and price expectation are significantly affect tomato quantity supplied to market. Out of significant variables distance from nearest market and price expectation are the variables which influences the dependent variable negatively.

Table 9. Determinants of tomato quantity supplied to market (OLS test)

\begin{tabular}{|l|l|l|}
\hline \multicolumn{1}{|c|}{ Quantity supply } & \multicolumn{1}{c|}{ Coefficient $P>|t|$} \\
\hline Distance from market & -0.0024 & $0.000^{* * *}$ \\
\hline All wither condition road & 0.0003 & 0.163 \\
\hline Own land & 0.0221 & $0.091^{*}$ \\
\hline Experience & 0.1044 & 0.537 \\
\hline Tomato yield & 0.0613 & $0.082^{*}$ \\
\hline Price per kilogram of tomato & 0.0134 & 0.609 \\
\hline Fertilizer & 0.0002 & 0.349 \\
\hline Purchase of insurance & 0.3841 & 0.812 \\
\hline Getting training & 0.8662 & $0.002^{* * *}$ \\
\hline Price expectation & -1.007 & $0.001^{* * *}$ \\
\hline Cons & 0.5391 & 0.139 \\
\hline $\mathrm{R}^{2}$ & 0.655 & \\
\hline F-value & 0.13 & \\
\hline
\end{tabular}

Note: ${ }^{* * *}$ represents significance at $1 \%$, and $*$ at $10 \%$.

Source: own computation

The degree of multicollinearity among the explanatory variables has been tested using VIF and $\mathrm{R}^{2}$.The results for all VIF were ranging between 1.56 and 2.49 , and $R^{2}$ was 0.655 . Hence, Since VIF is less than 10 and $R^{2}$ is below 0.90 . Therefore, multicollinearity cannot be suspected. Among the production factors: Distance from market and Price per kilogram of tomato influenced negatively and significantly tomato supplied to the market. It is true that price stimulate market supply. However, Tomek and Robinson (1985) argued that in the short run prices could not stimulate market supply due to the biological nature and time lag requirement of production. 
Analysis of Tomato Value Chain: The Case of Toke Kutaye District, West Shawa Zone, Oromia National, Regional Stat

Own land: This variable influenced tomato supply to market positively and significantly by $10 \%$ significance level. If farmers having own land increase by one hectare, probability of farmers tomato quantity supply to market can increase by $2.2 \%$. This might be due to the reason that, farmers who have more own land could invest more of his money on tomato production interms of renting land and using production improvement mechanism to supply more of their product to local market center and sell to wholesalers or retailers directly by getting better price which might go to the collectors.

Tomato yield: This variable influenced tomato supply to market positively and significantly by $10 \%$ significance level. If tomato yield is increased by one quintal/hectare tomato quantity supply to market can increased by $8.2 \%$. The possible justification is that in the study area, participation in tomato supply is higher for person who harvesting more of tomato yields from the given hectares of land.

Distance from nearest market: This variable is related to negatively and significantly, at less than or equal to percent probability level, to decision participation in tomato supply to market. This explanatory variable shows that, ceteris paribus, if the distance of household from nearest market is increased by one hour, that participating in tomato supply decreases by 0.2 percent. As a result, they may not join the tomato producers groups that are producing tomato production and supply to market.

Getting training: This variable influenced tomato supply to market positively and significantly by $1 \%$ significance level. All other things being kept constant, the marginal effect shows interest to participation in tomato supply activities increase by $86 \%$ percent as household get training regarding tomato production and marketing activity. The possible justification is that in the study area, participation in tomato supply is higher for person who got marketing and production activity training. Therefore, as household get training the less likely it is that he/ she makes market participation in tomato supply is increase.

Price expectation: This variable influenced tomato supply to market negatively and significantly by $1 \%$ significance level. All other things being kept constant, if price expectation is negatively affected, interest to participation in tomato supply activities decreases in the next year by $100 \%$ percent.

\section{CONCLUSION AND RECOMMENDATIONS}

\section{Conclusion}

Tomato produced in this area passes through several intermediaries, i.e. collectors, wholesalers and retailers, with little value being added before reaching the end-users. The intermediate buyers obtain tomato from the farmers at a lower price and they sell to the consumers at a higher price. The average price that sample respondents received for a quintal of tomato was reported to be $350 \mathrm{Br} /$ qts whereas the price those consumers paid was $800, \mathrm{Br} / \mathrm{qts}$, respectively. The research result also indicated the absence of organized institution and system group marketing, and lack of processing activities have made traders in a better position to dominate the roost in pricing. Tomato is highly perishable product and has to reach the consumer as fast as possible. This hands the power to buyers and due to this its governance is buyer driven. While farmers, doing all the work of producing tomato and bearing the associated risks, took only $5.7 \%$ of the profit margin. This disproportionate share of benefits is the reflection of power relationship among actors. The result of linear regression model indicates that marketable supply of tomato is significantly affected by distance from market, price expectation, getting training, own land and tomato yield. Therefore, these variables require special attention if marketable supply is to be increased.

\section{Recommendations}

The recommendations or policy implications to be drawn from this study are based on the significant variables from the analysis of present study. To start with, dissemination of modern input technologies is essential in increasing the productivity of tomato. 
Analysis of Tomato Value Chain: The Case of Toke Kutaye District, West Shawa Zone, Oromia National, Regional Stat

The results of econometric analysis indicate that tomato supply to the market is positively and significantly affected by tomato yield, own land, and getting training are significantly affect tomato quantity supplied to market supply. Therefore, it is recommended to arrange tomato yield improvement mechanism, improving land productivity methods and arranging relevant training for farmers are very important points which can improve tomato quantity supply to market.

Distances from nearest market and price expectation are the variable which influences the dependent variable negatively. Therefore, strengthening efficient and area specific extension systems, improving road infrastructure, supporting DAs by giving continuous capacity building trainings to improve farmers ability by arrange farmers practical based training and separating DAs extension work from other administrative activities increases quantity of tomato supply to the market. Generally, government should interfere and facilitate tomato value chain process and need to overcome the above problems and improve market supply of tomato production which can solve farmer's income problem and minimize food in security problem.

\section{ACKNOWLEDGEMENT}

First and foremost I would like to express my gratefulness to almighty God for enabling me to complete this research work successfully Next, I have strong gratitude to Ambo University who gave me a chance to fund the research and make it smoothen to complete the work. Finally, I have also recognition for the deliberation of staff members of Agricultural economics department for all achievements

\section{REFERENCE}

AbrahamTegegn. (2013). Value Chain Analysis of Vegetables: The Case of Habro and Kombolcha Woredas in Oromia Region, Ethiopia Msc. Thesis.

Achchuthan, S., \& Kajananthan, R. (2012). A Study on Value Chain Analysis in Dairy Sector KilinochchiDistrict, Sri Lanka, 12(21).

Ali Mohammad, Fauzia Bano Faruqi and Jamal Mustafa (2009). Edible compounds as antitumor agents Aligarh Muslim University, Indian Journal of Science and Technology Aligarh-202002, India.

Amikuzuno, J. and Ihle, R. (2010). Seasonal Asymmetric Price Transmission in Ghanaian Tomato Markets:Poster Presented at the Joint 3rd African Association of Agricultural Economists(AAAE) and 48th Agricultural Economists Association of South Africa (AEASA) Conference, Cape Town, South Africa, September 19-23, 2010.

Bezabah Emana, 2008. Value chain analysis of horticultural crops in Kombolcha districts of eastern Oromia Region, Ethiopia. A study conducted for Action Aid Ethiopia, Addis Ababa.

FAO, 2005. Addressing marketing and processing constraints that inhibit agrifood exports. A guide for policy analysts and planners, FAO Agricultural Services Bulletin 60, Rome..

Gary Gereffi \& KarinaFernandez-Stark,2011.Global Value Chain Analysis:Center on Globalization,Governance \& Competitiveness (CGGC) Duke University Durham, North Carolina, USA May 31, 2011

Gereffi, G. 1999. A commodity chains framework for analyzing global industries. Workshop on spreading the gains from globalization, University of Sussex, Institute of Development Studies.

Gereffi, G., Humphrey, J., \& Sturgeon, T. (2005). The governance of global value chains. Review of International Political Economy, 12(1), 78-104. https://doi.org/10.1080/09692290500049805

Greene, W., 2000. Econometric Analysis. 4th edn. NJ: Prentice Hall, Englewwod Cliffs Ethiopian Agriculture research institute(EARI) 2008. 
Analysis of Tomato Value Chain: The Case of Toke Kutaye District, West Shawa Zone, Oromia National, Regional Stat

Hamprecht, J., Corsten, D., Noll, M., \& Meier, E. (2005). Controlling the sustainability of food supply chains. Supply Chain Management: An International Journal, 10(1), 7-10. https://doiorg/10.1108/1359854051 0578315

Heijden and VinkN. (2010). A Critical Review of Current Approaches to Increasing Access To, 1-17.

Hobbs, J., A. Cooney, M. Fulton, 2000. Value market chains in the agrifood sector: What are they? How do they work? Are they for me? Department of Agricultural Economics, University of Saskatchewan,Canada.

Humphrey, J. (2004). Upgrading in global value chains World Commission on the Social Dimension of Globalization International Labour Office.

International Fund for Agricultural Development (IFAD),2006. Value chains, linking producers to the markets page 1 .

International Labor Organization(ILO)2007. Mayoux, L. \& Mackie, G. Making the strongest links. A practical guide to mainstream gender analysis in value chain analysis. Geneva.

Iruria, O. D. C., Odhiambo, D. M., \& Mairura, M. O. (2009). Economics evaluation of relative

Kaplinsky, R. and M. Morris , 2001. A handbook of value chain analysis. Working paper prepared for the IDRC, Institute for Development Studies, Brighton, UK.

Kotler, P. and G. Armstrong, 2003. Principle of marketing, 10th Edition. Hall of India Pvt. Ltd. New Delhi. pp 5-12.

McFadden, D., 1978. Quantal choice analysis: a survey. Annals of Economic and Social Measurement, 5(1976):363-390.

Microloan Foundation(2011).Value Chain Analysis: Tomato, Onion and Irish PotatoTKAD(Toke Kutaye Agriculture Development Office) 2014.

Ricketts, K. D., Turvey, C. G., \& Gómez, M. I. (2014). Value chain approaches to development Smallholder farmer perceptions of risk and. https://doi.org/10.1108/JADEE-10-2012-0025

Toke Kutaye Irrigation Authority Office (TKIAO) 2013. Irrigation authority annual report

Tomek, W.G. and K.L.Robinson, 1985. Agricultural Product Prices, 2nd-ed. Ithaca, N.Y. USA: Cornell University Press.

UNIDO (2011). Pro-poor Value Chain Development: 25 guiding questions for designing and implementing agroindustry projects. United Nations Industrial Development Organization (UNIDO). Vienna, Austria.

Webber, A. (2004). Using Value Chain Approaches in Sub-Saharan Africa.

Weignberger, K. and A. Lumpkin, 2005. Horticulture for poverty alleviation: The unfunded revolution: The World Vegetable Centre, AVRDC Publication No. 05-613, Shanhua, Taiwan.

Zylberberg, E. (2014). Bloom or bust ? A global value chain approach to smallholder flower production in Kenya. https://doi.org/10.1108/20440831311321638

Citation: Aman Rikitu, "Analysis of Tomato Value Chain: The Case of Toke Kutaye District, West Shawa Zone, Oromia National, Regional Stat". American Research Journal of Agriculture, V4, I1; pp:1-15

Copyright (C) 2018 Aman Rikitu, This is an open access article distributed under the Creative Commons Attribution License, which permits unrestricted use, distribution, and reproduction in any medium, provided the original work is properly cited.

American Research Journal of Agriculture

Page 15 